\title{
Meat Characteristic of Crossbred Local Chicken Fed Inulin of Dahlia Tuber and Lactobacillus sp.
}

\author{
Z. H. Abdurrahman ${ }^{\mathrm{a}, *}$, Y. B. Pramono ${ }^{\mathrm{b}}$, \& N. Suthama ${ }^{\mathrm{b}}$ \\ ${ }^{a}$ Department of Animal Science, Faculty of Animal Science, Boyolali University \\ Jalan Pandanaran No. 405, Boyolali 57313, Indonesia \\ ${ }^{b}$ Faculty of Animal and Agricultural Sciences, Diponegoro University \\ Jalan Prof. Soedarto, Tembalang, Semarang, Jawa Tengah, Indonesia \\ (Received 25-05-2016; Reviewed 13-07-2016; Accepted 26-07-2016)
}

\begin{abstract}
This study was conducted to evaluate the meat characteristic of crossbred local chicken fed diet containing both dahlia tuber powder as inulin source and probiotic Lactobacillus sp. The experimental animals were 168 crossbred local chickens which were randomly divided into 6 groups of treatment (4 replications each) when they were 21-d old. A completely randomized design with $2 \times 3$ factorial pattern consisted of 2 levels of prebiotic [(0.8\% (D1) and 1.2\% (D2)] and 3 levels of probiotic [without probiotic (L0), $1.2 \mathrm{~mL}(\mathrm{~L} 1)$, and $2.4 \mathrm{~mL}(\mathrm{~L} 2)]$ was arranged in the present study. One mL probiotic (Lactobacillus sp.) was equal to $10^{8} \mathrm{cfu}$. Results showed that the supplementation of prebiotic and probiotic significantly $(\mathrm{P}<0.05)$ affected breast meat color in terms of $\mathrm{L}^{*}$ (lightness) and $\mathrm{b}^{*}$ (yellowness). The meat fat mass and cholesterol was significantly $(\mathrm{P}<0.05)$ decreased by the combination of prebiotic and probiotic. The hardness of meat was not affected significantly by all treatments. The conclusion is that breast meat color could be improved, and both meat fat mass and cholesterol content could be decreased by feeding a combination of $\mathbf{1 . 2} \%$ dahlia tuber powder as inulin source and $\mathbf{1 . 2}$ $\mathrm{mL}$ probiotic Lactobacillus sp.
\end{abstract}

Key words: prebiotic inulin, probiotic Lactobacillus sp., meat characteristic, crossbred local chicken

\section{ABSTRAK}

Tujuan penelitian ini adalah untuk mengevaluasi karakteristik daging ayam lokal persilangan yang diberi ransum mengandung kombinasi prebiotik inulin dari umbi dahlia dan probiotik Lactobacillus sp. Penelitian menggunakan 168 ekor ayam lokal persilangan umur 21 hari yang secara acak ditempatkan pada 6 perlakuan dengan 4 ulangan. Rancangan acak lengkap pola faktorial $2 \mathrm{x}$ 3 diterapkan pada penelitian ini. Penambahan prebiotik sebanyak 0,8\% (D1) dan 1,2\% (D2) sebagai faktor pertama, dan penambahan probiotik yaitu tanpa probiotik (L0), probiotik 1,2 mL (L1), dan 2,4 mL (L2) sebagai faktor kedua. Satu mililiter probiotik (Lactobacillus sp.) setara dengan $10^{8} \mathrm{cfu}$. Hasil penelitian menunjukkan bahwa penambahan prebiotik dan probiotik pada ransum nyata $(P<0,05)$ mempengaruhi warna daging dada berdasarkan $L^{*}$ (tingkat kecerahan) dan $b^{*}$ (tingkat kekuningan). Massa lemak dan kolesterol nyata $(\mathrm{P}<0,05)$ menurun akibat penambahan prebiotik dan probiotik. Kekerasan daging tidak nyata dipengaruhi oleh perlakuan. Kesimpulannya adalah bahwa 1,2\% prebiotik dan probiotik $1,2 \mathrm{~mL}\left(10^{8} \mathrm{cfu} / \mathrm{mL}\right)$ adalah kombinasi yang paling optimum berdasarkan perbaikan warna daging dada dan penurunan massa lemak dan kolesterol daging.

Kata kunci: prebiotik inulin, probiotik Lactobacillus sp., karakteristik daging, ayam lokal persilangan

\section{INTRODUCTION}

Antibiotic has been used in the poultry industry for period of decade because it can improve the feed efficiency and performance. However, the use of antibiotic

${ }^{*}$ Corresponding author:

E-mail: zhabdurrahman@gmail.com in animal feed can cause negative effects on consumers. Since 2006, the use of antibiotic as a growth promoter has been banned in the European Union, because it might result the deposition of residues in meat and another edible component of poultry product. The development of pathogenic bacterial resistance is also the impact of continuously feeding antibiotic. Thus, it needs naturally alternative substance to substitute antibiotic, 
such as probiotic and/or prebiotic, which is human- and animal-healthy friendly.

Probiotics are 'live microorganisms' in sufficient quantities that can affect the digestive microflora composition and ecosystem so that providing a health benefit to the host (Hill et al., 2014). Probiotic can modify microflora in gastrointestinal ecosystem and help to increase nutrients digestibility (Mountzouris et al., 2010). The number of Lactobacilli and Bifidobacteria can be enhanced with prebiotics (Pourabedin \& Zhao, 2015). Definition of prebiotic was introduced in 1995 and was updated several times. The scientific community has continued to debate concerning what it means to be a prebiotic. Although the absence of a consensus definition, a principle element is that prebiotic should improve the health of host or otherwise provide a beneficial physiological effect (Hutkins et al., 2016). Feeding prebiotic would be more effective when combined with the addition of beneficial bacteria as probiotic because both are expected to be complementary as a symbiotic mutualism. Group of organisms known to be potentially function as probiotic are Lactobacillus sp.

Lactobacillus sp. is a beneficial bacteria commonly used in relation to the improvement of gastrointestinal condition in poultry. The characteristic function of probiotic (Lactobacillus sp.) would be optimal for the change in gastrointestinal ecosystem to be better when combined with the source of prebiotic. Inulin is a prebiotic with polyfructans classification which is widely used as prebiotic and found in dahlia tuber with inulin content about 15\%-20\% (Saeed et al., 2015). The balanced combination of probiotics and prebiotics could be function as synbiotic (Finamore et al., 2016). The prebiotic can be selectively fermented by a certain probiotic and other beneficial gastrointestinal microbiota into short-chain fatty acids (SFCA), mainly acetate, propionate, and butyrate, that lowered the luminal $\mathrm{pH}$ and decreased pathogenic bacteria (Pourabedin \& Zhao, 2015). However, the feeding application of both probiotic and prebiotic on Indonesian crossbred local chicken is still very rare and not much studied.

Local chicken is an Indonesian native poultry with plumage color tends to green and red. This local chicken is presumed the offspring of red jungle fowl (Gallus gallus) and green jungle fowl (Gallus varius). In case of commercial purposes, the productivity of local chicken can be improved by a system of crossbreeding between male local chicken and the female modern chicken. Ma'rifah et al. (2013) reported that the offspring of crossbreeding system tended to have similar exterior to their uncerstor (local chicken) and the meat texture was also not much different from that of local chicken at the same age. Therefore, the aim of the present study was to evaluate the effect of prebiotic inulin derived from dahlia tuber powder combined with probiotic using Lactobacillus sp. on color, hardness, fat mass, and cholesterol of crossbred local chicken meat.

\section{MATERIALS AND METHODS}

The formulation and nutritional contents of basal diet in the present study was completely similar to those reported by Abdurrahman et al. (2016) due to the continuation of the study. Diet was formulated with $19 \%$ protein and $2800 \mathrm{kcal} / \mathrm{kg}$ for starter period and $18 \%$ and $2800 \mathrm{kcal} / \mathrm{kg}$ for finisher period. Basal diet composed of corn, soybean meal, rice bran, fish meal, $\mathrm{CaCO}_{3}$, mineral, and vitamin (Table 1). The treatments were 2 levels of dahlia tuber powder combined with three levels of Lactobacillus sp. The experimental animals were 168 birds of 3-week old crossbred local chicken with an initial body weight was $164.45 \pm 2.97 \mathrm{~g}$ raised in battery cages and provided dietary treatment until 11-week. Chickens were fed at 06:00 am and 04:00 pm every day. A small portion of diet (more or less $30 \mathrm{~g}$ ) containing dahlia tuber powder and Lactobacillus sp. was given at 04:00 pm every afternoon in order to make sure that both components were consumed totally. The other portion of diets without dahlia tuber powder and Lactobacillus sp. were provided separately to fulfill the amount of daily requirement.

The treatments were $0.8 \%$ prebiotic without probiotic (D1L0); 0.8\% prebiotic combined with $1.2 \mathrm{~mL}$ probiotic (D1L1); $0.8 \%$ prebiotic combined with 2.4 $\mathrm{mL}$ probiotic (D1L2); $1.2 \%$ prebiotic without probiotic (D2L0); 1.2\% prebiotic combined with $1.2 \mathrm{~mL}$ probiotic (D2L1); $1.2 \%$ prebiotic combined with $2.4 \mathrm{~mL}$ probiotic (D2L2). Prebiotic inulin was derived from dahlia tuber powder and probiotic was Lactobacillus sp $\left(10^{8} \mathrm{cfu} / \mathrm{mL}\right)$. Variables observed were color, hardness, fat mass, and cholesterol content of meat.

Samples for meat color and hardness measurements were cutlet of breast and drumstick meat

Table 1. Ingredients and nutrients composition of the experimental basal $\operatorname{diet}^{1)}(\%)$

\begin{tabular}{lrr}
\hline \multicolumn{1}{c}{ Ingredient } & Starter & Finisher \\
\hline Yellow corn & 53.30 & 54.50 \\
Rice brand & 16.00 & 20.00 \\
Soybean meal & 19.50 & 15.00 \\
Fish meal & 10.00 & 9.30 \\
$\mathrm{CaCO}_{3}$ & 0.70 & 0.70 \\
Vitamin and mineral & 0.50 & 0.50 \\
Total & 100.00 & 100.00 \\
Nutrient composition (\%) & & \\
Metabolizable energy (kcal/kg) & $2,879.55$ & $2,879.16$ \\
Crude protein & 19.67 & 17.73 \\
Ether extract $^{* *}$ & 6.42 & 6.35 \\
Crude fiber $^{* *}$ & 6.38 & 6.60 \\
Methionine $^{*}$ & 0.42 & 0.40 \\
Lysine* $^{*}$ & 1.95 & 1.06 \\
Calcium $^{* * *}$ & 1.17 & 1.10 \\
Phospor $^{* * *}$ & 0.68 & 0.68 \\
\hline
\end{tabular}

Note:

${ }^{1)}$ Same formulation as that of Abdurrahman et al. (2016) due to the continuation of the study.

*Based on Table of Badan Standarisasi Nasional (2006) and National Research Council (1994); ${ }^{* *}$ Result of chemical analysis at The Laboratory of Animal Feed Science, Faculty of Animal Science, Hasanuddin University; ${ }^{* * *}$ Result of chemical analysis at the Laboratory of Animal Nutrition and Feed Science, Faculty of Animal and Agriculture Science, Diponegoro University (2013). 
(skinless). All parts of the skinless carcass meat were mixed and homogenized for fat mass and cholesterol determinations. The meat color measurements were carried out using Chroma Meter CR200 (Minolta, Osaka, Japan). Notation of color was characterized as Hunter color indexes L* (lightness), $\mathrm{a}^{*}$ (redness), and b* (yellowness) according to the method of Zhang et al. (2012). The meat hardness measurements were started by preparing meat samples cutlet about $1 \mathrm{~cm}^{3}$, which were easily to obtain from the selective parts of breast and drumstick meat. Testing meat texture (hardness) was performed with Lloyd Texture Analyzer TA-XT Plus (England). The hardness value was stated in gram force (gf) according to Suryanti et al. (2015). Meat fat was analyzed using Soxhlet Extraction method according to AOAC (2005). Meat fat mass was calculated using formula as follows: [mass of meat fat $=\%$ meat fat content $\mathrm{x}$ meat mass $(\mathrm{g})$ ]. Meat cholesterol was analyzed based on LeibermannBurchard method according to Fathullah et al. (2013), using a spectrophotometer at absorbance of $680 \mathrm{~nm}$. Cholesterol content is expressed in $\mathrm{mg} / \mathrm{g}$ sample.

Experiment was assigned in $2 \times 3$ factorial pattern of completely randomized design with 4 replications. The first factor was 2 levels of prebiotic, namely $0.8 \%$ (D1) and $1.2 \%$ (D2), whereas the second factor was 3 levels of probiotic, namely none (L0), $1.2 \mathrm{~mL}$ (L1), and $2.4 \mathrm{~mL}$ (L2). Data analysis was performed using SPSS software (Statistical Package for the Social Sciences, SPSS Inc., USA) subjected to F-test based on analysis of variance continued to Duncan multiple range test when the treatment indicated significant effect $(\mathrm{P}<0.05)$.

\section{RESULTS}

Supplementation of prebiotic combined with probiotic showed significant effect $(\mathrm{P}<0.05)$ on $\mathrm{L}^{*}$ (lightness) and $b^{*}$ (yellowness) (Table 2$)$. The highest $L^{*}$ value

Table 2. Breast meat color of crossbred local chicken fed diet containing prebiotic inulin derived from dahlia tuber powder combined with probiotic Lactobacillus sp.

\begin{tabular}{|c|c|c|c|c|}
\hline \multirow{2}{*}{$\begin{array}{l}\text { Level of dahlia } \\
\text { tuber powder }\end{array}$} & \multicolumn{3}{|c|}{ Level of Lactobacillus sp. } & \multirow{2}{*}{ Mean } \\
\hline & L0 & L1 & L2 & \\
\hline \multicolumn{5}{|l|}{$\mathrm{L}^{*}$} \\
\hline D1 & $56.90 \pm 2.91^{\mathrm{b}}$ & $60.74 \pm 0.84^{\mathrm{ab}}$ & $62.04 \pm 3.01^{a}$ & $59.89 \pm 3.19$ \\
\hline D2 & $60.38 \pm 1.77^{\mathrm{ab}}$ & $56.72 \pm 5.76^{b}$ & $57.92 \pm 1.96^{\mathrm{ab}}$ & $58.34 \pm 3.67$ \\
\hline Mean & $58.64 \pm 2.90$ & $58.73 \pm 4.38$ & $59.98 \pm 3.22$ & $59.12 \pm 3.46$ \\
\hline \multicolumn{5}{|l|}{$a^{*}$} \\
\hline D1 & $5.94 \pm 0.37$ & $4.87 \pm 0.38$ & $4.17 \pm 0.50$ & $4.99 \pm 0.42$ \\
\hline D2 & $3.16 \pm 0.78$ & $4.90 \pm 0.72$ & $4.53 \pm 0.20$ & $4.20 \pm 0.61$ \\
\hline Mean & $4.55 \pm 0.70$ & $4.88 \pm 0.53$ & $4.35 \pm 0.36$ & $4.60 \pm 0.53$ \\
\hline \multicolumn{5}{|l|}{$b^{*}$} \\
\hline D1 & $10.34 \pm 0.37^{\mathrm{ab}}$ & $12.47 \pm 0.30^{\mathrm{a}}$ & $10.72 \pm 0.24^{\mathrm{ab}}$ & $11.18 \pm 0.31$ \\
\hline D2 & $12.43 \pm 0.05^{\mathrm{a}}$ & $8.46 \pm 0.17^{b}$ & $9.65 \pm 0.41^{\mathrm{ab}}$ & $10.18 \pm 0.36$ \\
\hline Mean & $11.38 \pm 0.30$ & $10.47 \pm 0.40$ & $10.18 \pm 0.33$ & $10.68 \pm 0.34$ \\
\hline
\end{tabular}

Note: Means in the same row and column with different superscript differ significantly $(\mathrm{P}<0.05)$. D1=supplementation of prebiotic at $0.8 \%$; $\mathrm{D} 2=$ supplementation of prebiotic at $1.2 \%$; $\mathrm{L} 0=$ no supplementation of probiotic; L1= supplementation of probiotic at $1.2 \mathrm{~mL}\left(10^{8}\right.$ $\mathrm{cfu} / \mathrm{mL}) ; \mathrm{L} 2=$ supplementation of probiotic at $2.4 \mathrm{~mL}\left(10^{8} \mathrm{cfu} / \mathrm{mL}\right)$; $\mathrm{L}^{*}=$ lightness; $\mathrm{a}^{*}=$ redness; $\mathrm{b}^{*}=$ yellowness. was found due to the combination of prebiotic at $0.8 \%$ and probiotic at $2.4 \mathrm{~mL}$ (D1L2) and was significantly different from those of the combination of prebiotic at $0.8 \%$ without probiotic (D1L0) and prebiotic at $1.2 \%$ combined with probiotic at $1.2 \mathrm{~mL}$ (D2L1). The present study indicated difference result between breast and drumstick meat colors. The drumstick meat color measurement based on the values of $L^{*}$ (lightness), $a^{*}$ (redness) and $b^{*}$ (yellowness) indicated no significant different due to the supplementation of prebiotic combined with probiotic (Table 3). The supplementation of prebiotic combined with probiotic indicated no significant difference on the hardness of either breast or drumstick meat (Table 4). However, the different case was found with meat fat mass and meat cholesterol (Table 5) that was affected by the significant interaction $(P<0.05)$ of supplemental prebiotic and probiotic. The highest meat fat mass was achieved by the combination of $1.2 \%$ prebiotic without probiotic (D2L0) and significantly different to those of all treatment combinations except for the combination of $0.8 \%$ prebiotic without probiotic (D1L0). On the other hand, the combination of $1.2 \%$ prebiotic and probiotic at $2.4 \mathrm{~mL}\left(10^{8} \mathrm{cfu} / \mathrm{mL}\right)$ (D2L2) significantly showed the lowest meat fat mass except for the treatment of $1.2 \%$ prebiotic combined with probiotic at $1.2 \mathrm{~mL}\left(10^{8} \mathrm{cfu} / \mathrm{mL}\right)(\mathrm{D} 2 \mathrm{~L} 1)$.

\section{DISCUSSION}

The $\mathrm{L}^{*}$ value of breast meat of crossbred local chicken showed a range from 56.72 to 62.04 . Zhu et al. (2012) reported that the normal $L^{*}$ value of broiler breast meat was between 48 and 53. In contrast, other studies (Battula et al., 2008; Sheard et al., 2012; Al-Owaimer et al., 2014) have shown different results with values that were outside this range. The different value of breast meat color found in the present study was presumably due to

Table 3. Drumstick meat color of crossbred local chicken fed diet containing prebiotic inulin derived from dahlia tuber powder combined with probiotic Lactobacillus sp.

\begin{tabular}{crccc}
\hline \multirow{2}{*}{$\begin{array}{c}\text { Level of dahlia } \\
\text { tuber powder }\end{array}$} & \multicolumn{3}{c}{ Level of Lactobacillus sp. } & \multirow{2}{*}{ Mean } \\
\cline { 2 - 4 } L0 & & L1 & L2 & \\
\hline L & $57.84 \pm 2.82$ & $56.78 \pm 2.90$ & $58.66 \pm 3.99$ & $57.76 \pm 3.07$ \\
D2 & $54.66 \pm 0.67$ & $56.14 \pm 1.15$ & $56.91 \pm 1.74$ & $55.90 \pm 1.50$ \\
Mean & $56.25 \pm 2.55$ & $56.46 \pm 2.07$ & $57.78 \pm 3.00$ & $56.83 \pm 2.55$ \\
a* & & & & \\
D1 & $7.00 \pm 0.58$ & $6.44 \pm 0.19$ & $5.83 \pm 0.69$ & $6.42 \pm 0.49$ \\
D2 & $7.59 \pm 0.34$ & $8.34 \pm 0.31$ & $7.74 \pm 0.72$ & $7.89 \pm 0.45$ \\
Mean & $7.29 \pm 0.45$ & $7.39 \pm 0.30$ & $6.79 \pm 0.68$ & $7.16 \pm 0.49$ \\
b* & & & & \\
D1 & $7.56 \pm 0.52$ & $7.81 \pm 2.64$ & $5.79 \pm 2.95$ & $7.06 \pm 2.29$ \\
D2 & $10.37 \pm 2.68$ & $8.01 \pm 2.04$ & $5.57 \pm 2.98$ & $7.98 \pm 3.17$ \\
Mean & $8.96 \pm 2.34$ & $7.91 \pm 2.19$ & $5.68 \pm 2.75$ & $7.52 \pm 2.74$ \\
\hline
\end{tabular}

Note: D1=supplementation of prebiotic at $0.8 \%$; $2=$ supplementation of prebiotic at $1.2 \%$; $\mathrm{L} 0=$ no supplementation of probiotic; $\mathrm{L} 1=$ supplementation of probiotic at $1.2 \mathrm{~mL}\left(10^{8} \mathrm{cfu} / \mathrm{mL}\right)$; L2= supplementation of probiotic at $2.4 \mathrm{~mL}\left(10^{8} \mathrm{cfu} / \mathrm{mL}\right) ; \mathrm{L}^{*}=$ lightness; $\mathrm{a}^{*}=$ redness; $b^{*}=$ yellowness. 
Table 4. Breast and drumstick meat hardness (gf) of crossbred local chicken fed diet containing prebiotic inulin derived from dahlia tuber powder combined with probiotic Lactobacillus sp.

\begin{tabular}{ccccc}
\hline \multirow{2}{*}{$\begin{array}{c}\text { Level of dahlia tuber } \\
\text { powder }\end{array}$} & L0 & Level of Lactobacillus sp. & \multirow{2}{*}{ Mean } \\
\cline { 2 - 4 } Breast meat & $1603.87 \pm 0.07$ & $1729.41 \pm 0.10$ & $1494.73 \pm 0.06$ & $1609.34 \pm 0.07$ \\
D1 & $1855.56 \pm 0.08$ & $2005.25 \pm 0.20$ & $1646.14 \pm 0.10$ & $1835.65 \pm 0.13$ \\
D2 & $1729.72 \pm 0.08$ & $1867.33 \pm 0.15$ & $1570.43 \pm 0.08$ & $1722.49 \pm 0.10$ \\
Mean & & & & \\
Drumstick meat & $1734.63 \pm 0.21$ & $2482.61 \pm 0.09$ & $1936.34 \pm 0.14$ & $2051.19 \pm 0.16$ \\
D1 & $1709.44 \pm 0.11$ & $1563.30 \pm 0.31$ & $1369.72 \pm 0.23$ & $1547.49 \pm 0.22$ \\
D2 & $1722.03 \pm 0.16$ & $2022.96 \pm 0.26$ & $1653.03 \pm 0.20$ & $1799.34 \pm 0.20$ \\
Mean & & & L2 & \\
\hline
\end{tabular}

Note: D1=supplementation of prebiotic at $0.8 \%$; D2= supplementation of prebiotic at $1.2 \%$; L0= no supplementation of probiotic; L1= supplementation of probiotic at $1.2 \mathrm{~mL}\left(10^{8} \mathrm{cfu} / \mathrm{mL}\right) ; \mathrm{L} 2=$ supplementation of probiotic at $2.4 \mathrm{~mL}\left(10^{8} \mathrm{cfu} / \mathrm{mL}\right) ; \mathrm{gf}=$ gram-force.

Table 5. Fat mass and cholesterol of meat of crossbred local chicken fed diet containing prebiotic inulin derived from dahlia tuber powder combined with probiotic Lactobacillus sp.

\begin{tabular}{ccccc}
\hline \multirow{2}{*}{$\begin{array}{c}\text { Level of dahlia tuber } \\
\text { powder }\end{array}$} & \multicolumn{3}{c}{ Level of Lactobacillus sp. } & \multirow{2}{*}{ Mean } \\
\cline { 2 - 4 } Meat fat mass $(\mathrm{g} / \mathrm{bird})$ & & L1 & L2 & $31.49 \pm 0.46$ \\
D1 & $37.20 \pm 0.28^{\mathrm{ab}}$ & $29.65 \pm 0.34^{\mathrm{bc}}$ & $27.64 \pm 0.26^{\mathrm{bc}}$ & $28.36 \pm 1.34$ \\
D2 & $44.25 \pm 0.45^{\mathrm{a}}$ & $23.03 \pm 1.29^{\mathrm{cd}}$ & $17.80 \pm 0.46^{\mathrm{d}}$ & $29.93 \pm 1.00$ \\
Mean & $40.73 \pm 0.45$ & $26.34 \pm 0.97$ & $22.72 \pm 0.66$ & \\
Meat cholesterol (mg/g) & & & & $1.02 \pm 0.12$ \\
D1 & $1.09 \pm 0.09^{\mathrm{ab}}$ & $0.90 \pm 0.02^{\mathrm{d}}$ & $1.06 \pm 0.08^{\mathrm{abc}}$ & $1.03 \pm 0.06$ \\
D2 & $1.01 \pm 0.02^{\mathrm{bc}}$ & $0.99 \pm 0.04^{\mathrm{c}}$ & $1.10 \pm 0.04^{\mathrm{a}}$ & $1.02 \pm 0.09$ \\
Mean & $1.05 \pm 0.07$ & $0.94 \pm 0.06$ & $1.08 \pm 0.06$ & \\
\hline
\end{tabular}

Note: Means in the same row and column with different superscript differ significantly $(\mathrm{P}<0.05)$. D1=supplementation of prebiotic at $0.8 \%$; $\mathrm{D} 2=$ supplementation of prebiotic at $1.2 \%$; L0 = no supplementation of probiotic; $\mathrm{L} 1=$ supplementation of probiotic at $1.2 \mathrm{~mL}\left(10^{8} \mathrm{cfu} / \mathrm{mL}\right)$; $2=$ supplementation of probiotic at $2.4 \mathrm{~mL}\left(10^{8} \mathrm{cfu} / \mathrm{mL}\right)$.

probiotic strain, source of prebiotic, and chicken strain or genotype dependent. Feeding broiler with prebiotic mannanoligosacharides (MOS) and probiotic based on Lactobacillus acidophillus and casei, and Streptococcus lactis and faecium, and Bifidobacteruim bifidum (Pelicano et al., 2005; Aristides et al., 2012) indicated no effects, but that with Bacillus licheniformis (Liu et al., 2012) significantly increased breast meat color. The higher $\mathrm{L}^{*}$ value of breast meat of crossbred local chicken compared to that of imported breeds was consistence with the finding of Jaturasitha et al. (2008) that breast meat color of Thai native chicken was higher than that of Rhode Island Red. Chicken genotype or strain was considered to be the important factor contributing to the lightness of meat which is much more preferable for the consumers. Indigenous-blood chickens (crossbred local chicken) have lower fat and cholesterol contents due to the higher muscular contraction since their active movement compared to modern breeds. The point of view concerning the muscular biochemical process is decribed in the following description.

The increase in $\mathrm{L}^{*}$ value was assumed to be related to myosin activity, a myofibrils protein where ATPase enzyme production take place. Bowker et al. (2004) reported that color of muscle depends on the type of muscle fiber and ATPase activity. White muscle in the carcass contains many anaerobic white muscle fibers with high glycogen content, and has a higher ATPase activity. Jao et al. (2007) reported that myosin is a myofibrils protein that responsible to the ATPase enzyme production. The study of Abdurrahman et al. (2016) showed that the supplementation of inulin derived from dahlia tuber powder as a source of prebiotic combined with Lactobacillus sp. as a probiotic source increased the protein mass of crossbred kampong chicken meat. In connection with the previous studies, it can be assumed that the increased meat protein mass of crossbred local chicken due to the supplementation of prebiotic combined with probiotic followed by the increase in myosin content. Thus, the highest value of lightness breast meat found in D1L2 could be associated with the highest meat protein mass as it was previously reported by Abdurrahman et al. (2016).

The difference of $b^{*}$ value of the breast meat can be associated with antioxidant activity, because it can inhibit the oxidation of hemoglobin. Abdurrahman et al. (2016) found that the supplementation of inulin derived from dahlia tuber powder as a source of prebiotic combined with Lactobacillus sp. can affect antioxidant activity in meat. This finding is consistent with a research conducted by Jang et al. (2008) that the change in the value of antioxidant activity measured by DPPH can 
modify the color of meat, although it was indirect based on the value of $b^{*}$, by reducing the oxidation of hemoglobin and activating mechanisms that modify the distribution of the pigment in animal tissues. The change in $b^{*}$ value in this study can be also related to the difference in meat fat deposition, because meat containing more fat has higher $b^{*}$ value than that containing less fat. This result was in agreement with Zhou et al (2009) who showed that the fat content in the breast meat can modifies the value of $b^{*}$.

The difference result between breast and drumstick was assumed to be caused by the different structure and movement activities of both muscles. It is well-known that drumstick glycogen content and ATPase activities of drumstick muscle were lower than those of breast muscle. Liu \& Xiong (2015) reported that drumstick muscle (red muscle) had lower glycogen content and ATPase activities than breast muscles (white muscle).

Besides meat color, hardness was an important quality indicator which determining the meat selling value to consumers and very often related to the meat protein content. Troy \& Kerry (2010) reported that hardness was an indicator of consumer preference of acceptance on meat quality. Keeton et al. (2014) found that the major protein components in meat were connective tissue, myofibril, and sarcoplasm. As it was reported by Abdurrahman et al. (2016) that meat protein mass of crossbred kampong chicken was significantly increased by feed supplemented with dahlia tuber powder combined with Lactobacillus sp. Therefore, the increase in mass of meat proteins should be followed by the increase in collagen, because it was the main protein of connective tissue which responsible for the hardness. However, in the present study, the increase in meat protein mass was not followed by the increase in collagen content, because collagen was assummed to be quite small in the total of meat protein. Although collagen is the major connective tissue protein as reported by Astruc (2014), connective tissue protein comprised only about $2 \%$ of total protein in poultry meat (Keeton et al., 2014). Therefore, the increase in meat protein mass due to the supplementation of dahlia tuber powder combined with Lactobacillus sp. could not affect the concentration of collagen, so that the hardness was not affected significantly by the treatments. Lepetit (2007) reported that the increase in meat hardness can be explained by the increase in the amount of meat collagen. Similar to the report of Maiorano et al. (2012) that the increase in meat hardness is related to the change in collagen concentration.

Modifications of the concentration and strength of collagen increased with the age of the birds due to the increase in covalent cross-linking during the growth and development of poultry muscle (Kong et al., 2008; Petracci \& Cavani, 2012). However, the present result regarding the supplemental effect of prebiotic combined with probiotic did not significantly increase the meat hardness since the experimental bird used were at the same age. This finding was in agreement with the report of Brzoska et al. (2010) indicated that dietary probiotic was not related to the hardness of meat.
The decrease in meat fat mass related to the change in the composition and activity of gut microflora due to the supplementation of dahlia tuber powder as a source of inulin combined with Lactobacillus sp. This result is in agreement with the report of Krismiyanto et al. (2014) that the increased lactic acid bacteria (LAB) population was due to the feeding effect of inulin derived from dahlia tuber which can intensely fermented by endogenous beneficial bacteria. Thus, the drecreased fat meat content and cholesterol concentration found in the present study can be associated with the increase in bile salt hydrolase (BSH) enzyme produced by the enhanced growth of LAB (Fajrih et al., 2014). This biochemical mechanism will be discussed further in the following paragraph, especially for cholesterol metabolism. The decrease in meat fat mass was consistent with some previous reports (Al-Lahham et al., 2010; Ooi \& Liong, 2010; Weitkunat et al., 2015) that the short chain fatty acids (acetate, butyrate, propionate) produced by the fermentative effect of lactic acid bacteria on inulin were assumed to have important contribution. Propionate, for example, could exert controlling effect on lowering hepatic lipogenesis, and the inhibition of lipogenesis process related to the decrease in meat fat content.

In addition, the decrease in meat fat mass can also be connected with the ability of probiotic in decreasing the activity of the lipogenic enzymes of acetyl-CoA carboxylase which stimulates fatty acid synthesis by producing statins as inhibitors of the hepatic lipogenesis. This finding was supported by Yakhkeshi et al. (2012) that the decrease in acetyl-CoA carboxylase enzyme activity could decrease the hepatic lipogenesis because the deposition of meat fat was derived from fat synthesis via hepatic lipogenesis. Cavallini et al. (2009) reported that lactic acid bacteria can produce statins, namely a substance as an inhibitors of 3-hydroxy-3-methyl-glutarin CoA reductase which is function as regulator enzyme of fat biosynthesis, cholesterol, and triglycerides. This fat reduction mechanism started when the inhibitor reduced cholesterol in hepatocytes and improved the performance of high density lipoprotein (HDL) so that it can reduce the fat content.

The increasing number of lactic acid bacteria (LAB) as described previously can be linked to the mechanism of cholesterol reduction in meat by bile salt hydrolase (BSH). Bile salt hydrolase (BSH) can modify conjugated bile salt into deconjugated bile salt which is less absorbable and easily dispose through excreta. Sudha et al. (2009); Kumar et al. (2013); Rai et al. (2013) suggested that LAB produced BSH in the duodenum could break the C-24 amide $\mathrm{NaCl}$ down between bile acids and amino acids, and further change it into deconjugated bile salt. The addition of probiotic can increase the amount of BSH produced in the gut, with the result of decreasing amount of absorbed cholesterol to be metabolized and deposited into the meat. Also, the disposed bile salt need to be recovered from the part of absorbed cholesterol and bring about the low cholesterol level. Therefore, based on the mechanism described above, meat cholesterol in this study was decreased by the addition of probiotic. Conversely, the lower additional 
probiotic caused the low number of beneficial bacteria in the gut, thus the mechanism of cholesterol formation was ocurred in the absence of inhibition mechanism. This condition caused the metabolizable cholesterol in significant amounts and providing impact on the high cholesterol in birds given $1.2 \%$ prebiotic without probiotic (D2L0) and also those fed $0.8 \%$ prebiotic without probiotic (D1L0) (Table 5). However, cholesterol level increased in the treatment of prebiotic either $0.8 \%$ or $1.2 \%$ combined with $2.4 \mathrm{~mL}$ probiotic (D1L2 and D2L2). Similar finding was reported by Daud et al. (2007) that birds received probiotic and prebiotic either independently or in combination at low level was not able to reduce meat cholesterol concentration because of probiotic at that level was unable to produce sufficient BSH enzyme with its activity to decrease cholesterol level. It was also likely due to the hepatic synthesis of endogenous cholesterol is predictably more dominant, while the disposal cholesterol from the body together with bile acids is very slight. On the contrary, intestinal cholesterol absorption increased so that the meat cholesterol level is also getting high.

\section{CONCLUSION}

Dietary supplementation of prebiotic inulin derived from dahlia tuber at $1.2 \%$ combined with single probiotic based on Lactobacillus sp. at $1.2 \mathrm{~mL}\left(10^{8} \mathrm{cfu} / \mathrm{mL}\right)$ was able to improve breast meat color and to decrease both fat mass and cholesterol of crossbred local chicken meat.

\section{ACKNOWLEDGEMENT}

This study was funded by the Goverment of Indonesia through Directorate General of Resource for Science, Technology, and Higher Education Scholarships 2013.

\section{REFERENCES}

Abdurrahman, Z. H., Y. B. Pramono, \& N. Suthama. 2016. Feeding effect of inulin derived from dahlia tuber combined with Lactobacillus sp. on meat protein mass of crossbred kampong chicken. J. Indonesian Trop. Anim. Agric. 41:3744. http://dx.doi.org/10.14710/jitaa.41.1.37-44

Al-Lahham, S. H., P. P. Maikel, H. Roelofsen, R. J. Vonk, \& K. Venema. 2010. Biological effects of propionic acid in humans; metabolism, potential applications and underlying mechanisms. Biochim. Biophys. Acta 1801:1175-1183. http://dx.doi.org/10.1016/j.bbalip.2010.07.007

Al-Owaimer, A. N., G. M. Suliman, A. H. Alyemni, \& A. M. Abudabos. 2014. Effect of different probiotics on breast quality characteristics of broilers under Salmonella challenge. Ital. J. Anim. Sci. 13:450-454. http://dx.doi. org/10.4081/ijas.2014.3189

AOAC. 2005. Official Methods of Analysis of AOAC International. 18 $8^{\text {th }}$ Ed. Assoc. Official Anal. Chem., Arlington.

Aristides, L. G. A., F. G. Paiao, L. S. Murate, A. Oba, \& M. Shimokomaki. 2012. The effects of biotic additives on growth performance and meat qualities in broiler chickens. Int. J. Poult. Sci. 11:599-604. http://dx.doi.org/10.3923/ ijps.2012.599.604

Astruc, T.. 2014. Carcass Composition, Muscle Structure, and Contraction. In: M. Dikeman \& C. Devine (Eds). Encyclo- pedia of Meat Sciences $2^{\text {nd }} E d$. Academic Press, London. pp. 148-166. http://dx.doi.org/10.1016/B978-0-12-3847317.00099-4

Badan Standarisasi Nasional. 2006. Pakan anak ayam ras pedaging (ayam broiler starter) (Starter broiler feed). Standar Nasional Indonesia (SNI) 01-3930-2006.

Battula, V., M. W. Schilling, Y. Vizzier-Thaxton, J. M. Behrends, J. B. Williams, \& T. B. Schmidt. 2008. The effects of low-atmosphere stunning and deboning time on broiler breast meat quality. Poult. Sci. 87:1202-1210. http://dx.doi. org/10.3382/ps.2007-00454

Bowker, B. C., A. L. Grant, D. R. Swartz, \& D. E. Gerrard. 2004. Myosin heavy chain isoforms influence myofibrillar ATPase activity under simulated postmortem $\mathrm{pH}$, calcium, and temperature conditions. Meat Sci. 67:139-147. http:// dx.doi.org/10.1016/j.meatsci.2003.09.016

Brzoska, F., M. Pieszka, K. Stecka, W. Migdal, E. Wesierska, M. Walczycka, K. Krzysztoforski, \& O. Michalik-Rutkowska. 2010. Effect of Pediococcus spp. in feed instead of antibiotic on broiler chicken body weight, mortality, slaughter traits and meat quality. Ann. Anim. Sci. 10:167-177.

Cavallini, D. C., R. Bedani, L. Q. Bomdespacho, R. C. Vendramini, \& E. A. Rossi. 2009. Effects of probiotic bacteria, isoflavones and simvastatin on lipid profile and atherosclerosis in cholesterol-fed rabbits: a randomized double-blind study. Lipids Health Dis. 8:1-8. http://dx.doi. org/10.1186/1476-511X-8-1

Daud, M., W. G. Piliang, \& I. P. Kompiang. 2007. Persentase dan kualitas karkas ayam pedaging yang diberi probiotik dan prebiotik dalam ransum. (Carcass percentage and quality of broilers given ration containing probiotic and prebiotic). Indonesian J. Anim. Vet. Sci. 12:167-174. (Abstract in English).

Fajrih, N., N. Suthama, \& V. D. Yunianto. 2014. Body resistance and productive performance of crossbred local chicken fed inulin of dahlia tubers. Med. Pet. 37:108-144. http://dx.doi. org/10.5398/medpet.2014.37.2.108

Fathullah., N. Iriyanti, \& I. H. Sulistiyawan. 2013. Penggunaan pakan fungsional dalam ransum terhadap bobot lemak abdomen dan kadar kolesterol daging ayam broiler (The use of functional feed on the weight of abdominal fat and cholesterol level in broiler chicken meat). J. Ilmiah Pet. 1:119128. (Abstract in English).

Finamore, A., I. Peluso, \& M. Serafini. 2016. Synbiotics: A New Strategy to Improve the Immune System from the Gut to Peripheral Sites. In: R. R. Watson \& V. R. Preedy (Eds). Probiotics, Prebiotics, and Synbiotics: Bioactive Foods in Health Promotion. Academic Press, London. p. 567-574. http://dx.doi.org/10.1016/B978-0-12-802189-7.00041-1

Hill, C., F. Guarner, G. Reid, G. R. Gibson, D. J. Merenstein, B. Pot, L. Morelli, R. B. Canani, H. J. Flint, S. Salminen, P. C. Calder, \& M. E. Sanders. 2014. Expert consensus document: The International Scientific Association for probiotics and prebiotics consensus statement on the scope and appropriate use of the term probiotic. Nat. Rev. Gastroenterol. Hepatol. 11:506-514. http://dx.doi.org/10.1038/ nrgastro.2014.66

Hutkins, R. W., J. A. Krumbeck, L. B. Bindels, P. D. Cani, G. Fahey, Y. J. Goh, B. Hamaker, E. C. Martens, D. A Mills, R. A. Rasta, E. Vaughan, \& M. E. Sanders. 2016. Prebiotics: why definition matter. Curr. Opin. Biotechnol. 37:1-7. http://dx.doi.org/10.1016/j.copbio.2015.09.001

Jang, A., X. D. Liu, M. H. Shin, B. D. Lee, S. K. Lee, J. H Lee, \& C. Jo. 2008. Antioxidative potential of raw breast meat from broiler chicks fed a dietary medicinal herb extract mix. Poult. Sci. 87:2382-2389. http://dx.doi.org/10.3382/ ps.2007-00506

Jao, C. L., J. S. Hwang, W. C. Ko, \& K. C. Hsu. 2007. A kinetic study on inactivation of tilapia myosin Ca-ATPase in- 
duced by high hydrostatic pressure. Food Chem. 101:6569. http://dx.doi.org/10.1016/j.foodchem.2005.11.051

Jaturasitha, S., T. Srikanchai, M. Kreuzer, \& M. Wicke. 2008. Differences in carcass and meat characteristics between chicken indigenous to northern Thailand (Black-boned and Thai native) and imported extensive breeds (Bresse and Rhode Island Red). Poult. Sci. 87:160-169. http:// dx.doi.org/10.3382/ps.2006-00398

Keeton, J. T., S. M. Ellerbeck, \& M. T. Nunez de Gonzalez. 2014. Chemical and Physical Characteristics Of Meat: Chemical Composition. In: M. Dikeman \& C. Devine (Eds). Encyclopedia of Meat Sciences $2^{\text {nd }}$ Ed. Academic Press, London. p. 235-243. http://dx.doi.org/10.1016/B978-0-12384731-7.00087-8

Kong, F., J. Tang, M. Lin, \& B. Rasco. 2008. Thermal effects on chicken and salmon muscles: Tenderness, cook loss, area shrinkage, collagen solubility and microstructure. LWTfood Sci. Tech. 41:1210-1222. http://dx.doi.org/10.1016/j. lwt.2007.07.020

Krismiyanto, L., N. Suthama, \& H. I. Wahyuni. 2014. Feeding effect of inulin derived from Dahlia variabilis tuber on intestinal microbes in starter period of crossbred native chickens. J. Indonesian Trop. Anim. Agric. 39:217-233. http:// dx.doi.org/10.14710/jitaa.39.4.217-223

Kumar, R., H. Rajkumar, M. Kumar, S. R. Varikuti, R. Athimamula, M. Shujauddin, R. Ramagoni, \& N. Kondapalli. 2013. Molecular cloning, characterization and heterologous expression of bile salt hydrolase (BSH) from Lactobacillus fermentum NCDO394. Mol. Biol. Rep. 40:5057-5066. http://dx.doi.org/10.1007/s11033-013-2607-2

Lepetit, J. 2007. A theoretical approach of the relationships between collagen content, collagen cross-links and meat tenderness. Meat Sci. 76:147-159. http://dx.doi.org/10.1016/j. meatsci.2006.10.027

Liu, X., H. Yan, L. Lv, Q. Xu, C. Yin, K. Zhang, P. Wang, \& J. Hu. 2012. Growth performance and meat quality of broiler chickens supplemented with Bacillus licheniformis in drinking water. Asian-Aust. J. Anim. Sci. 25:682-689. http:// dx.doi.org/10.5713/ajas.2011.11334

Liu, C. \& Y. L. Xiong. 2015. Oxidation-initiated myosin subfragment cross-linking and structural instability differences between white and red muscle fiber types. J. Food Sci. 80:288-297. http://dx.doi.org/10.1111/1750-3841.12749

Ma'rifah, B., U. Atmomarsono, \& N. Suthama. 2013. Nitrogen retention and productive performance of crossbred native chicken due to feeding effect of kayambang (Salvinia molesta). Int. J. Sci. Eng. 5:19-24. http://dx.doi.org/10.12777/ ijse.5.1.19-24

Maiorano, G., A. Sobolewska, D. Cianciullo, K. Walasik, G. Elminowska-Wenda, A. Sławinska, S. Tavaniello, J. Zylinska, J. Bardowski, \& M. Bednarczyk. 2012. Influence of in ovo prebiotic and synbiotic administration on meat quality of broiler chickens. Poult. Sci. 91:2963-2969. http:// dx.doi.org/10.3382/ps.2012-02208

Mountzouris, K. C., P. Tsitrsikos, I. Palamidi, A. Arvaniti, M. Mohnl, G. Schatzmayr, \& K. Fegeros. 2010. Effects of probiotic inclusion levels in broiler nutrition on growth performance, nutrient digestibility, plasma immunoglobulins, and cecal microflora composition. Poult. Sci. 89:58-67. http://dx.doi.org/10.3382/ps.2009-00308

National Research Council. 1994. Nutrient Requirements of Poultry. $9^{\text {th }}$ Revised Ed. National Academy Press. Washington DC.
Ooi, L. G. \& M. T. Liong. 2010. Cholesterol-lowering effects of probiotics and prebiotics: A review of in vivo and in vitro findings. Int. J. Mol. Sci. 11:2499-2522. http://dx.doi. org/10.3390/ijms11062499

Pelicano, E. R. L., P. A. Souza, H. B. A. Souza, A. Oba, M. M. Boiago, N. M. B. L. Zeola, A. M. Scatolini, V. A. Bertanha, \& T. M. A. Lima. 2005. Carcass and cut yield and meat qualitative traits of broilers fed diets containing probiotics and prebiotics. Braz. J. Poult. Sci. 7:169-175. http://dx.doi. org/10.1590/s1516-635x2005000300006

Petracci, M. \& C. Cavani. 2012. Muscle growth and poultry meat quality issues. Nutr. 4:1-12.

Pourabedin, M. \& X. Zhao. 2015. Prebiotics and gut microbiota in chickens. FEMS Microbiol. Lett. 362:fnv122. http:// dx.doi.org/10.1093/femsle/fnv122

Rai, A. K., P. Debetto, \& F. D. Sala. 2013. Molecular regulation of cholesterol metabolism: HDL-based intervention through drugs and diet. Indian J. Exp. Biol. 51:885-894.

Saeed, M., I. Yasmin, I. Pasha, M. A. Randhawa, M. I. Khan, M. A. Shabbir, \& W. A. Khan. 2015. Potential application of inulin in food industry: A review. Pak. J. Food Sci. 25:110116.

Sheard, P. R., S. I. Hughes, \& M. H. Jaspal. 2012. Colour, pH and weight changes of PSE, normal and DFD breast fillets from British broilers treated with a phosphate-free, low salt marinade. Br. Poult. Sci. 53:57-65. http://dx.doi.org/10. 1080/00071668.2012.655707

Sudha, M. R., P. Chauhan, K. Dixit, S. Babu, \& K. Jamil. 2009. Probiotics as complementary therapy for hypercholesterolemia. Biol. Med. 1:1-13.

Suryanti, U., V. P. Bintoro, U. Atmomarsono, \& Y. B. Pramono. 2015. Physical characteristics of culled magelang duck meat affected by aging and marination in ginger extract. J. Indonesian Trop. Anim. Agric. 40:107-114. http://dx.doi. org/10.14710/jitaa.40.2.107-114

Troy, D. J. \& J. P. Kerry. 2010. Consumer perception and the role of science in the meat industry. Meat Sci. 86:214-226. http://dx.doi.org/10.1016/j.meatsci.2010.05.009

Weitkunat, K., S. Schumann, K. J. Petzke, M. Blaut, G. Loh, \& S. Klaus. 2015. Effects of dietary inulin on bacterial growth, short-chain fatty acid production and hepatic lipid metabolism in gnotobiotic mice. J. Nut. Biochem. 26:929937. http://dx.doi.org/10.1016/j.jnutbio.2015.03.010

Yakhkeshi, S., S. Rahimi, \& H. R. H. Matin. 2012. Effects of yarrow (Achillea millefolium L.), antibiotic and probiotic on performance, immune response, serum lipids and microbial population of broilers. J. Agr. Sci. Tech. 14:799-810.

Zhang, Z. F., T. X. Zhou, X. Ao, \& I. H. Kim. 2012. Effects of $\beta$-glucan and Bacillus subtilis on growth performance, blood profiles, relative organ weight and meat quality in broilers fed maize-soybean meal based diets. Livest. Sci. 150:419-424. http://dx.doi.org/10.1016/j.livsci.2012.10.003

Zhou, T. X., Y. J. Chen, J. S. Yoo, Y. Huang, J. H. Lee, H. D. Jang, S. O. Shin, H. J. Kim, J. H. Cho, \& I. H. Kim. 2009. Effects of chitooligosaccharide supplementation on performance, blood characteristics, relative organ weight, and meat quality in broiler chickens. Poult. Sci. 88:593-600. http:// dx.doi.org/10.3382/ps.2008-00285

Zhu, X. S., X. L. Xu, H. H. Min, \& G. H. Zhou. 2012. Occurrence and characterization of pale, soft, exudative-like broiler muscle commercially produced in China. J. Integr. Agric. 11:1384-1390. http://dx.doi.org/10.1016/S20953119(12)60137-3 